Revista Iberoamericana, Vol. LXXIII, Núm. 221, Octubre-Diciembre 2007, 887-902

\title{
NI APOCALÍPTICOS NI INTEGRADOS: MEDIOS AUDIOVISUALES EN TRES NARRADORES DEL SUR DE AMÉRICA
}

\author{
POR \\ Jesús Montoya JuÁReZ \\ Universidad de Granada
}

La omnipresencia de la cultura audiovisual ha influido decisivamente en la reflexión teórica sobre la posmodernidad. En Jameson la virtualidad y los medios son elementos clave en la construcción del espacio y tiempo posmodernos, descritos por él mediante las metáforas del "pastiche” y la "esquizofrenia”. Representar el espacio como "pastiche" supone conciliar elementos de culturas diversas y productos incluso catalogados como de mal gusto o kitsch, reciclarlos e incorporarlos como códigos del discurso artístico. El tiempo como "esquizofrenia” confiere al presente una relación problemática con el pasado histórico, que se percibe como un conjunto de presentes desconectados entre sí. Para la sociedad actual se hace difícil elaborar una imagen global de su presente, de ahí que para Jameson la sensación de realidad se esté perdiendo ante la omnipresencia de infinidad de imágenes fragmentadas y contradictorias de lo real que saturan la capacidad de interpretación de los sujetos y caen rápidamente en el olvido. Una idea similar desarrolla Baudrillard, para quien la "sociedad del espectáculo", con el desarrollo de los medios de comunicación, deviene "sociedad de la ceremonia”, la alienación moderna, en “éxtasis de la comunicación”, convirtiendo la realidad en un simulacro que se propone obscenamente como más real que lo real (El otro). Para Baudrillard la realidad se anula en un vanishing point (punto de desvanecimiento) con su transformación en “imágenes en tiempo real” (La ilusión). Sólo percibimos el simulacro que ha llegado a suplantar a lo real mismo.

Las novelas que vamos a analizar -Sueños digitales (2000) de Edmundo Paz Soldán, Caras extrañas (2001) de Rafael Courtoisie y La mendiga (1998) de César Airapromueven un concepto de real que poco tiene que ver con las categorías del realismo tradicional, jugando en todas ellas un papel central las tecnologías de la información y la comunicación en sus diversas realizaciones: lo melodramático televisivo, el videoclip, las computadoras como extensiones del cuerpo humano, el grotesco tecnológico del cómic o los dibujos animados, la disolución de fronteras entre lo virtual y lo real, la digitalización fotográfica, el ciberespacio o los videogames, forman una parte central de sus propuestas. El concepto de "real" que construyen los textos analizados cuestiona decididamente el verosímil realista convirtiéndose en la mejor descripción de la pérdida de densidad de la realidad. ${ }^{1}$

\footnotetext{
${ }^{1}$ Somos conscientes de que en la percepción de un texto como realista es determinante la productividad de la recepción y las variantes culturales que la determinan (Villanueva; Even-Zohar). Sin embargo, y a pesar de la complicación a este respecto introducida por la narrativa metaficcional
} 
Del diferente uso de los elementos tecnológico-televisivos, de sus diversas soluciones narrativas y conexiones con el contexto cultural latinoamericano de fin de siglo, se desprenden actitudes que superan la tradicional oposición apocalípticos/integrados que a propósito de la expansión posmoderna de la mass culture esbozara Umberto Eco (2004). La crítica latinoamericana, en relación con una idea similar a la “oportunidad” posmetafísica de cierto posmodernismo, interpreta la fragmentación de los metarrelatos como incertidumbre y, a la vez, como desafío, el de la construcción de nuevos proyectos utópicos desde la intemperie, la periferia de las ruinas de una biblioteca que se había constituido en metáfora de la modernidad (Achugar) o con las esquirlas o cenizas de las utopías de los años sesenta (Hopenhayn), ahora que la desarticulación de las voces totalizadoras de la modernidad, o de su "lado oscuro", la colonialidad (Mignolo) así lo permiten. Como lo expresa Volek “[...] el contexto posmoderno es más propicio para la reinvención de la identidad latinoamericana; porque fue mucho más difícil, para el latinoamericanismo, buscar una identidad a través de conceptos importados que lo colocaban en posición de inferioridad” (9).

La presencia de diferentes tecnologías audiovisuales en las novelas que analizaremos a continuación se muestra vinculada al diálogo con el horizonte teórico posmoderno, que para ninguno de los autores es desconocido. En los textos, junto a la descripción de esa pérdida de densidad de lo real en que deviene la vida cotidiana en la contemporaneidad, existe la tematización de la tensión entre la posibilidad-imposibilidad de una utopía en el arte, una presentación autorreflexiva del simulacro, una reflexión sobre la incidencia e interrelación de tecnología, literatura y vida, en conexión, desde nuestra perspectiva, con la teoría posmoderna y la crítica cultural latinoamericana. El propósito de este artículo no es sólo rastrear los elementos virtuales que se encuentran en los textos, sino también señalar cómo se integra en ellos la tecnología audiovisual posmoderna y sugerir cómo ésta funciona en sus proyectos narrativos.

\section{El Río Fugitivo de Paz Soldán o cómo llegamos a ser Sueños digitales}

El autor boliviano de Río fugitivo (1998) y El delirio de Turing (2003), plantea en Sueños digitales la narración de la desrealización de lo que tradicionalmente conocíamos por real con la penetración masiva de la tecnología virtual: el dibujo del espacio de la cotidianidad entre la percepción de la realidad sobresaturada de estímulos hiperreales que procede de la virtualidad de las computadoras, Internet, la fotografía digital, la publicidad o la televisión, y que se desliza dentro de esa cotidianidad humana que a los ojos del protagonista se muestra cada vez más irreal, decrépita y deprimente. Aunque el autor se vale de la construcción de una ciudad imaginada -Río Fugitivo, trasunto de su natal Cochabamba- en la que se desarrolla la trama, la novela, en su cuestionamiento de los límites entre realidad virtual y cotidianidad real que se redefine a partir de aquella, no abandona en ningún caso el pacto de verosimilitud realista, si bien dicho pacto está

y posmoderna, nos sigue pareciendo útil para entendernos la distinción estructural de Todorov entre los diferentes pactos de verosimilitud (realista, fantástico o maravilloso), atendiendo a la aparición o no del elemento fantástico, inexplicable racionalmente, y a su problematización o no en el interior del texto. 
transido por la experiencia, compartida por el receptor, de una cotidianidad en la que otros mundos virtuales están presentes: alude a lo que hoy es susceptible de ser real.

Sueños digitales plantea no pocos de los themes popularizados por la clásica narrativa de ciencia ficción que proyecta “distopías” en futuros alternativos (o no) a partir del cruce de medios de control de la información y tecnologías audiovisuales. Sin embargo, a diferencia de la ciencia ficción o del cyberpunk, ${ }^{2}$ Paz Soldán no requiere del elemento fantástico, no necesita imaginar nuevas tecnologías o nuevas presencias y oscuros usos de las mismas. La combinatoria del paisaje urbano latinoamericano, las estridencias de los anuncios publicitarios, la arquitectura hipermoderna y posmoderna, la saturación televisiva de los canales por cable y la realidad virtual de las computadoras se sobrepone a una realidad barrial deteriorada, repetidamente descrita con las mismas palabras; la realidad ajena a las luces y colores sobresaturados del centro se constituye ahora en fantasmagoría, en clisé, en algo que dudosamente puede ser definido como real. La realidad "hiperreal" del centro urbano se deshace en barrio periférico:

Aceleró el paso. La luz del alumbrado público carecía de fuerza pasado el puente. El río era una frontera que separaba la ciudad luminosa de la zona de sombra. Barrios de casas decrépitas, donde vivían aquellos que habían escapado de la pobreza pero no habían terminado de dar el salto a la seguridad económica. Ventanas azuladas por la luz de los televisores, Volkswagens brasileros estacionados en la calle, triciclos tirados en las aceras, perros insolentes y gatos advenedizos. (32)

En la contemplación de la "ciudad luminosa” parece hacerse presente un futuro inmediato. Eso piensa el protagonista, Sebastián, cuando mira la ciudad por la ventana:

Se le ocurrió que algún día [...] el futuro hacía implosión sobre el presente, [...] uno podría elegir el pedazo de realidad que se apoyaría en las ventanas. Uno estaría en Río Fugitivo, trabajando frente a la pantalla, y apretaría un botón y aparecería de pronto el monumental contorno de los rascacielos de Manhattan -ruidos de helicópteros y ambulancias y acaso un gorila en la punta del Empire State. (60-1)

La visibilidad funciona con valor ambivalente. La elección vital para todos los personajes protagónicos está en decidir lo que se presenta la mayoría de las ocasiones como no elegible, id est, el lado de la cámara: la egolatría del escenario o el voyeurismo de quien contempla el espectáculo. Pero en tiempos de visibilidad absoluta el poder se halla detrás, en la zona del conocimiento -nunca total- y el control -nunca del todo posible- del simulacro, a la que en la novela repetidamente se alude como "zona de sombra”, ahora en sentido positivo, como espacio deseable y no alcanzable. Sebastián, diseñador gráfico, es quien mejor encarna ese deseo de anonimato del artista, ocupar la zona de sombra en la que se cocinan los entresijos de la historia. Por el contrario, la visibilidad mediática sí se muestra accesible. El “salto a los medios”, la transformación del sujeto en imágenes para consumo, forma parte de la trayectoria de algunos personajes,

${ }^{2}$ Aunque este último reoriente los temas de la ciencia ficción aproximando los mundos futuro y presente, vinculando así sus a menudo oscuros universos alternativos a la experiencia de la vida cotidiana en las sociedades posmodernas (Cavallaro 14). 
como es el caso de la purista defensora de la fotografía tradicional, Inés, acusada de inducir al suicidio para obtener su reportaje.

La fórmula del escándalo mediático, reducido a clisé (Watergate, Yomagate, Narcogate), es un género informativo de una televisión posmoderna (Waisword) tendente al reality en el que se evidencia la desconstrucción de la dicotomía realidad-ficción (Verón). Sueños digitales adopta elementos del thriller político inspirado en el escándalo, mirado desde la distancia, ya que no se centra en las figuras públicas, sino en los efectos de la corrupción en la cotidianidad mediatizada de la clase media. Cada uno de los personajes de la novela es a un tiempo productor y consumidor de simulacros, cuya superposición crea una red cada vez más densa de simulación. Sebastián, diseñador gráfico del periódico Tiempos Posmodernos, contratado por el Ministerio de Informaciones, acepta eliminar fragmentos del pasado político mediante la manipulación digital de fotografías comprometedoras del período militar. Pese a colaborar en la corrupción de la memoria nacional, sólo puede observar a través de los medios los cambios en una realidad que camina por delante de él y que no puede controlar. El pasado acaba transformado, la memoria es elástica: la realidad se borra.

El theme de la poshistoria está fuertemente representado en la novela. Sueños digitales sugiere la idea de un fin que ya ha tenido lugar, la percepción de que la propia contemporaneidad se ha convertido en una especie de diferido de una realidad ya extinta y reciclada hasta la extenuación a través de sus imágenes, como sugiere la teoría posmoderna. ${ }^{3}$ La nostalgia histórica, el deseo a sabiendas imposible de vivir directamente los hechos se traduce en una fetichización de la historia, convertida en imagen consumible. Lo importante es el "cholulismo" de saberse ahí, mejor dicho, de "soñarse” ahí, en los momentos en que la historia ocurre, no importa de qué lado. Y para ello se hace necesaria la materialización de lo soñado en imágenes virtuales. Por eso las fotografías del viaje de novios en Antigua de Sebastián y su esposa, Nikki; por eso las polaroids de la Mamá Grande, una de las vecinas de Sebastián, a su marido; por eso Pixel, compañero en Tiempos Posmodernos de Sebastián, decora su apartamento con imágenes globalmente reconocibles del último tercio del siglo $\mathrm{xx}$ :

Sebastián miró las fotos en blanco y negro en las paredes, en las que Pixel se había insertado digitalmente. En una, Pixel era un oficial más posando junto al Che en una escuelita de Vallegrande, antes de que lo fusilaran. En otra, miraba con indiferencia a la niña vietnamita que, desnuda, corría escapando a un bombardeo yanqui con napalm. Abrazaba al chino que se enfrentaba a los tanques antes de la masacre de Tiannamen. [...] Era un edecán de Pinochet en La Moneda. (76-7)

La incorporación de los espacios virtuales de la televisión o Internet en la novela, la familiaridad con que los personajes hablan y emplean los nuevos entornos cibernéticos, convirtiéndose en usuarios -lectores y productores- de la tecnología (Landow), la simbiosis ser humano-máquina (Baudrillard “Videosfera...”; Hayles) encarnada en la adicción de Pixel, pero también en Sebastián, que sólo es capaz de pensar como seres digitales a las mujeres reales que conoce, la presencia de un televisor encendido de modo

\footnotetext{
${ }^{3}$ Esta idea puede leerse en: Baudrillard El otro, La ilusión; Jameson; Vattimo El fin; Lipovetski.
} 
casi continuado, haciendo que las preguntas por lo que ocurre tengan a menudo un doble referente, todo ello apunta a la cotidianización de la virtualidad que la crítica posmoderna ha puesto de relieve. En el discurso del narrador hallamos la lexicalización paródica de títulos o citas de textos teóricos canónicos. La repetición, explicitación, literalidad de las referencias refuerza la idea de saturación irónica que se aleja de la insinuación metafórica, en una práctica estética conscientemente posmoderna. De este modo vemos subrayarse en el discurso narrativo una familiaridad con el corpus teórico de autores ya clásicos como Eco o Lyotard. Los títulos de Apocalípticos e integrados o La posmodernidad explicada a los niños aparecen reiteradamente, parodiados, en la novela: "un historiador acucioso, de esos que investigaban sus pistas con lupa (o con programas más avanzados que Photoshop) repararía en un detalle que no casaba y descubriría que esa foto tan real había sido violada (la pornografía explicada a los intelectuales)” (220). El intertexto de Eco constituye uno de los ejes de la novela. Los personajes protagónicos se hallan vinculados a una tecnología de la que se muestran dependientes o incluso adictos. Las posturas apocalípticas, en cuyo extremo está la del padre de Sebastián, irónicamente refugiado en Colorado, Estados Unidos, en una vida de asceta, sin teléfono ni computadora, son contempladas por los jóvenes como algo ridículamente romántico, anacrónico o incomprensible. La fascinación que manifiestan los protagonistas más jóvenes por las novedades informáticas, por el mercado musical globalizado o los programas importados de la televisión americana o argentina, dibuja el retrato de una generación que ha crecido en la presencia de la televisión, de unos jóvenes cuyas retinas indiferentes se hallan sobresaturadas por el espectro virtual, para los que el paisaje rural boliviano les es mucho más extraño que la formidable silueta de la Gran Manzana:

Al salir de la ciudad se encontró con barrios de casuchas miserables, que ostentaban con orgullo una antena de televisión. El espacio urbano no duraba más de diez minutos; luego el campo, la pobreza. Se sintió mal: era fácil, en su mundo, olvidarse del país en que vivía. (130)

Sebastián y Pixel, amigos y compañeros en el periódico, cada cual a su modo, ejemplifican una misma ansiedad generacional por confirmar la densidad material de su existencia, la realidad de la propia subjetividad. Ambos personajes se construyen como usuarios de entornos virtuales y, a su vez, acaban disolviéndose de modo diferente en esa virtualidad. Si Pixel se introduce en el juego virtual por computadora (MUD: Multi-User Dungeon) asumiendo el rol de Laracroft, Sebastián, en cambio, verá desaparecer su imagen de todas las fotografías de los álbumes de su esposa, desaparición virtual que preludia la desaparición de su vida, ${ }^{4}$ su desaparición física mediante el anacrónico gesto de arrojarse desde el Puente de los Suicidas, rogando que no haya una cámara que capture ese instante.

\footnotetext{
${ }^{4}$ La desaparición final de su vivienda puede leerse como el único elemento que quiebra el pacto realista: la realidad física como una enorme fotografía digital manipulable. Pero el narrador deja en territorio ambiguo tanto la desaparición de su imagen en las fotos como la de su vivienda, sugiriéndonos un proceso intimidatorio a cargo de La Ciudadela, los secuaces de Montenegro.
} 
Los “seres digitales”, construcciones pastiche generadas por Sebastián para la contratapa del suplemento cultural del periódico a partir de simulacros fotográficos combinados, convocan la idea cinematográfica de la "posproducción”: la recombinación de elementos reciclados, imágenes que la revolución, la moda o la academia convirtieron en iconos, perdido en el tiempo su significado. El juego se inicia con la conjunción de la cabeza del Che y el cuerpo de Raquel Welch, un collage convertido en "parodia neutra" que se agota en sí misma. En la novela hay por un lado una teoría del arte que, a pesar de las contradicciones que la tecnología introduce, huye del polo apocalíptico: "Ni retratista, ni pintor, ni fotógrafo, ni diseñador gráfico, ni creativo. Un artista. Nada más. Nada menos” (101); por otro lado, la terrible duda, la irónica necesidad de confirmar un modo de considerarse artista: "Si no eres fotógrafo digital, ¿qué eres? [...] -¿Qué soy? -dijolo que diga ella [...]-Mejor no opino. [...] Pero a él le hubiera gustado saber qué era. Qué, quién, por qué, y por qué no” (99).

Queda además representada en la novela la tensión entre el deseo utópico de vincular arte y praxis social, empleando el resquicio en forma de una “s” camuflada entre los píxeles de cada foto de Montenegro retocada por Sebastián en La Ciudadela, como un mensaje esquizofrénico en clave que recupere el pasado al tiempo que lo destruye, y la otra cara del espejo, la constatación de que no hay modo posible de vanguardia ajena a los intereses neoliberales, reduciéndose todo a un baile de cadáveres. El resultado del arte de Sebastián, sus seres digitales, no tienen más destino que el de extenderse como una capa de irrealidad sobre Río Fugitivo, como un cáncer, enfermedad de la materialidad de un cuerpo degradado, que se arrastra en el inconsciente, a pesar del simulacro..$^{5}$ Los únicos sueños imaginables para Sebastián se parecen demasiado a la descripción de la realidad mediatizada: "soñaba con Seres Digitales paseando su hibridez en una ciudad llena de edificios magenta, donde rondaba un hombre conocido como el Bibliotecario y la gente se suicidaba desde un puente" (129).

\section{Gramática audiovisual en Caras extrañas de Rafael Courtoisie}

La presencia de la tecnología audiovisual en Caras extrañas del uruguayo Rafael Courtoisie, en cambio, tiene que ver fundamentalmente con la gramática constructiva del relato y con el pacto de verosimilitud que plantea. Tres géneros televisivos cruzan su influencia en la prosa de Courtoisie: la telenovela, la parodia pulp de la violencia de los filmes de acción hollywoodenses, y el discurso fragmentado, plano-contraplano, que remeda el videoclip. La narración sigue una estructura fragmentada, a partir de secuencias que se mezclan y saltan atrás y adelante en el tiempo, constituyendo historias que se pierden para reaparecer más tarde. La novela está por tanto recorrida por esta técnica caleidoscópica y una gramática acelerada de lo audiovisual:

\footnotetext{
${ }^{5}$ Ramos González sugiere la solución del suicidio como una vuelta a la corporeidad, a la mortalidad del cuerpo como posibilidad de pensarse "fuera de las lindes de completa usurpación que prometen los movimientos agenciados desde los centros gubernamentales” (490). Sueños digitales plantea, ante las nuevas reglas de juego marcadas por la omnipresencia tecnológica, una aceptación realista de las nuevas condiciones, sin fatalismos apocalípticos, pero de dicha aceptación se desprende una solución de tintes sombríos: la muerte como único puente a la vacía utopía del silencio.
} 
La señora de Olmos, a la que le habían hecho un trabajo, está muerta, desparramada sobre la silla de estera. Las piernas abiertas. / Sangra la boca./ -Vamos- dice el primer soldado. 4

Olmos no sabe que quedó viudo. / Está desnudo, sobre la cama, con la rubia que le hizo el trabajo a su mujer para quedarse con él, con Olmos, con el marido que ahora es viudo. / La rubia se inclina y lame el antojo de Olmos. Lo lame. / Están solos. / Escuchan el tiroteo a lo lejos. [...] / La rubia le pide a Olmos que abra la boca. Olmos abre la boca. Le pide que la cierre. Olmos cierra la boca. Le pide que le diga algo al oído. -¿¿estás loca?- dice Olmos, y en ese momento entra una bala por la ventana y le parte el pecho a la rubia. / La rubia agoniza. Olmos se viste. (30)

Caras extrañas narra la herida en la intimidad de un yo narrador niño, que asiste indirectamente a unos acontecimientos violentos relacionados con los años previos al golpe militar de 1973, concretamente, la toma de la ciudad de Pando en 1969 por los Tupamaros y la posterior represión del ejército uruguayo. La novela, que se mueve en la frontera entre los géneros de la narrativa, la poesía y el ensayo, juega con los aspectos más grotescos de lo posible, por tanto real, dibujando una caricatura que nos hace sonreír en sus numerosos golpes de humor negro. Lo "fractal” define el modo de expresión narrativa de Courtoisie: el desorden, lo fragmentario, la disolución de las fronteras entre géneros configuran un "modo poético" de razonar en su narrativa, calificado por el propio Courtoisie como característico de la posmodernidad. ${ }^{6}$

Lo audiovisual en Courtoisie está sobre todo en una mirada sobre la realidad que transforma el objeto observado. El concepto de real que plantea la novela se construye mediante la acumulación excesiva de elementos que están en el plano de lo posible, provocando un efecto paródico que transforma el verosímil.

Las referencias al mundo de lo cinematográfico y lo televisivo se convierten en literales, en muchas ocasiones, como por ejemplo en la presencia de personajes como Robert Altman durante el copamiento, para rodar la segunda parte de The Birds de Hitchcock. El recurso a lo telenovelesco late en las secuencias que plantean la relación amorosa entre los hijos del coronel jefe de interrogatorios y un guerrillero muerto en la toma, Ana Saldías y Luis Antonio Aldao. La referencia es literal en otra historia: la de Marcela Salinas, hija de Simón Salinas, militar operado de riñón el día del copamiento, y Jorge, hijo del cirujano y de una guerrillera. El grotesco hace sonreír:

-¿De quién sería el riñón de tu padre?

-Quién sabe..., hay que preguntarle a tu padre, el cirujano.

-Mi padre murió hace tiempo.

-Entonces es un misterio.

-Sí, es un misterio - dijo Jorge y le desprendió la blusa a Marcela, le soltó el pelo castaño y los pechos.

-Es un misterio -suspiró Marcela, buena.

\footnotetext{
${ }^{6}$ Así la define Courtoisie: "Yo creo que la razón poética, así como hay una razón positivista, una razón ordenada, una razón de trabajo, de lógica formal en la modernidad, incluso en el trabajo en términos científicos de termodinámica, que tiene que ver con la maquinaria, con lo progresivo. En la posmodernidad, hay una razón poética, que trabaja con formas espontáneas de conocimiento y con iluminaciones, en el sentido de Rimbaud” (2004).
} 
Otra vez la telenovela. Primer plano: Se besan. El hijo de la guerrillera muerta y la hija de un riñón ajeno. (107-8)

Queda en el aire flotando la pregunta de si es posible restañar las heridas, más allá del olvido, queda expresado un deseo de reconciliación en términos de folletín televisivo, al que se superpone el Courtoisie más lírico, un deseo abierto que no es más que eso:

Ana Saldías, hija del coronel torturador Pedro Saldías y Luis Antonio Aldao, hijo de un guerrillero muerto a los veinticuatro años [...] se besaron. [...] La telenovela otra vez. ¿Pueden besarse las piedras? ¿Acaso se besa el movimiento del agua? [...] ¿ Puede besarse el hierro de los clavos? Quién sabe. Lo cierto es que Luis Antonio Aldao y Ana Saldías se besan en la boca, se tocan la lengua, se lamen, se mojan el caracol de la saliva, la jirafa, el ciervo, la vaca, el corazón violentamente. (110)

La mayor parte de los personajes que aparecen en el libro se nos antojan soportes en función de la narración. Su falta de densidad convierte la violencia e incluso la muerte en un instrumento retórico al servicio del espectáculo irónico que el autor despliega, al estilo de un Quentin Tarantino. En las primeras cuarenta páginas el número de muertes de diferentes personajes supera las veinticinco, la mayoría descritas en su grotesca y a menudo divertida ridiculez. La sonrisa se congela en el rostro, cuando recordamos la herida en el inconsciente de la sociedad uruguaya trazada por los sucesos narrados; la distancia de la caricatura se deshace cuando, debajo de todo el espectáculo que nos resulta risible por la gratuidad de sus excesos, encontramos la huella de una realidad que supera la ficción y resulta con frecuencia más sórdida:

-Muy bien, Saldías, excelente idea. ¿Ve como usted es un hombre capaz? Por algo lo recomendé para una promoción. Y se la van a otorgar, Saldías, no tenga dudas. El Estado Mayor sabe cómo premiar a su mejor personal. Lo felicito. [...] Siéntese, coronel. [...] [...] Al poner su cuerpo en la silla evitó apoyar la espalda. Permaneció unos segundos algo inclinado hacia adelante, apenas unos milímetros, doblado a causa de la fatiga de torturar. $[\ldots]$

$-\dot{¿}$ Y cómo lo va a enterrar? Me refiero al abono...

-Voy a dar orden de ponerlos paraditos. (88-9)

El pacto de verosimilitud lúdico que el texto construye con el lector remeda el de programas construidos a modo de pastiche a partir de fragmentos enlatados. En la novela caben secuencias ajenas por completo al hilo narrativo, digresiones líricas, asociaciones de ideas sobre la composición de las palabras, chistes, citas literales de canciones populares, de tango, incluso el autor en primera persona irrumpe en un diálogo con sus lectores:

Me pongo en los zapatos de un militar honrado, sobre sus suelas clavadas y pienso: No soy malo. ¿Por qué me echan la culpa a mí? Me pongo en el lugar de un milico y no me gusta que me manden a la puta que me parió. No, no me gusta. Algunos son buenos, honrados, cariñosos con sus hijos. A ellos, y a sus hijos, les pido que sonrían al escuchar esta canción: En un bosque de la China, un milico se perdió, ojalá se pierdan todos la puta 
que los parió. [...] Los bosques de la China están llenos de honesta sabiduría, no es malo o del todo desafortunado extraviarse en ellos. [...] No cierre el libro. (174)

Toda la novela, a través de la narración distanciada, construida bajo una óptica televisiva, apela al entretenimiento, a lo lúdico, en ocasiones a una risa más o menos abierta, para encontrar al término de ella la sensación de que lo real, a pesar del espectáculo, ha estado siempre delante de los ojos, y a veces es necesario desenfocar, aplicar una óptica que ponga en evidencia los aspectos grotescos de lo real, para deconstruir los relatos que unos y otros construyeron sobre los hechos históricos. Si el verosímil apunta a lo maravilloso-espectacular en su acumulación excesiva de elementos grotescos, en un contexto en el que una parte vital de nuestra cotidianidad la componen espacios virtuales como la televisión o el ciberespacio, la mirada televisiva supone una nueva forma de hacer realismo.

\section{Televisión y proyecto artístico en La mendiga de César Aira}

En la literatura de Aira escrita desde fines de los años ochenta la tecnología audiovisual tiene una presencia central. En La mendiga, el intertexto telenovelesco mezclado con elementos perfectamente asignables al videogame o a los dibujos animados, y una temática de fondo inspirada en la ciencia posmoderna (la reproducción asistida y la genética), contribuyen decididamente a reconstruir el verosímil y funcionan como condicionantes de la trama, de las reflexiones de narrador y personajes o de la propia gramática constructiva del relato. ${ }^{7}$

A estos tres modos en que influyen las tecnologías de lo audiovisual en la novela que analizamos debemos añadir un cuarto: al leer una novela como La mendiga, tenemos la sensación de que una parte del sentido de esa omnipresencia de la tecnología audiovisual continúa mostrándose hermética. Aira no sólo se limita a expresar una idea de "real” que se vincula con la idea posmoderna de simulacro, la novela no habla exclusivamente de la crisis contemporánea de la representación, de la verdad o del sentido de la propia realidad, sino que, además, funciona como elemento conscientemente "basurizador" que configura una especial identidad de la novela como objeto artístico. Cumple, por tanto, un papel devaluador o, mejor, desestabilizador del criterio de calidad de la obra de arte, en un diálogo que va más allá de la interpretación del mensaje de la propia obra. En los textos que Graciela Montaldo denomina "marca-Aira” la tecnología audiovisual de los medios de comunicación de masas juega un papel complejo, constituyéndose también en parte de un gesto en el que puede leerse una voluntad de estilo del no-estilo, una autodevaluación consciente de la obra, en un diálogo con la institución y mercado literarios.

Lo audiovisual mediático afecta a la narración a nivel argumental: los personajes son actores de una telenovela y las fronteras entre los espacios del universo real tradicional, mimético, que inicialmente parece plantear la novela, y del universo virtual-televisivo,

\footnotetext{
${ }^{7}$ Nos referimos a la teleserie Nueve lunas, emitida en Argentina en 1994, cuyas historias atraviesan el ámbito común del consultorio compartido por un doctor y una doctora, ambos ginecólogos y obstetras “[...] que tratan casos de embarazo en la adolescencia, fertilización asistida, [...] problemas de incesto y el acoso de la sexualidad” (sinopsis extraída de http://www.volver.com.ar/archivo.asp).
} 
que emerge dentro de aquél, se difuminan hasta llegar a desaparecer. En La mendiga, como en muchas de las novelas aireanas de los noventa, el espacio virtual acaba fagocitando el entorno aparentemente realista en el que el lector había encuadrado a la protagonista inicial, hasta que, finalmente, toda la realidad de la novela llega a borrarse en la absoluta virtualidad. Todo y todos, incluidos los personajes, acaban disolviéndose en un fundido al pasado requerido por el guión de la telenovela que protagonizan y en que se hallan inmersos, requiriendo de la lectura la construcción de un nuevo verosímil en el territorio de lo maravilloso.

\begin{abstract}
El fundido al pasado se hacía mediante una ondulación de las imágenes... una ondulación que barría con todo lo visible y empezaba a disgregarlo, ante la mirada perpleja de Cecilia. El cuartito se estremecía en convulsiones ópticas, y ella misma se sentía arrastrada, ondulando como una cortina de voile, separándose en puntos de luz... El fenómeno se extendía más allá de los biombos a todo el edificio, a todo el complejo del hospital, a los árboles del parque. (51)
\end{abstract}

En la novela el continuum del discurso televisivo como totalidad construye el verosímil narrativo. ${ }^{8}$ El fantástico aireano, a partir de la incorporación del lenguaje de la televisión a un discurso narrativo inicialmente realista, combina a modo de pastiche elementos de extraordinario mal gusto, fragmentos incoherentes que se prolongan a menudo en exceso y que luego pretenden ser justificados de modo grotesco, descripciones detalladas de las causas de fenómenos tangenciales o secundarios a la trama, juegos de palabras aparentemente ridículos, inofensivos o insustanciales que se convierten posteriormente en claves de realidad y de reflexión teórica a lo largo de la novela, traducen, en lo formal discursivo, el continuum televisivo.

El tono improvisado, las incoherencias argumentales que se justifican inverosímilmente, la voluntariedad en lo fallido, vienen a ser rasgos que definen muchas de las producciones aireanas de los años noventa. En La mendiga, una vez más, no existe una mera parodia, es decir, no se trata únicamente de un rescate, a través de la ironía camp, de los géneros discursivos folletinescos de la teleserie..$^{9}$ No es, simplemente, una parodia en segundo grado de lo real a través de la parodia de un discurso que ya es una versión degradada de lo real (el de géneros como la telenovela o los dibujos animados). Se trata, además, de la apropiación del lenguaje de la televisión para insertar un discurso metaficcional o metacrítico en el que la presencia de lo mediático contribuye al oscurecimiento del mensaje, a la propia desconstrucción de los sentidos que podríamos inferir de su lectura, en definitiva, a la puesta en duda de cualquier interpretación de su propio discurso. Valga el fragmento citado como ejemplo de la neutralidad de la parodia

\footnotetext{
${ }^{8}$ González Requena en su estudio sobre la televisión posmoderna apunta las características del discurso televisivo en tanto macrodiscurso, más allá de su descomposición en géneros. La mendiga parece reproducir el funcionamiento discursivo televisivo como totalidad, incorporando otros lenguajes (dibujos animados, documental, filme de ciencia ficción) sobre una base telenovelesca. ${ }^{9}$ Sandra Contreras, con Montaldo, señala cómo la literatura de Aira excede la definición de Sontag de lo camp, como buen gusto del mal gusto. El hermetismo de la ironía camp de Aira puede leerse, como hace Graciela Montaldo, como una relación irónica con la industria literaria.
} 
de Aira, donde se asiste, en el melodramático encuentro final de los amantes al cabo de los años, a una explicación saturada de absurdo, gotas de ciencia ficción y mitología:

\begin{abstract}
-Cómo te iba a escribir, si creía que estabas muerto [...] - ¡Yo no podía morir, Rosa! Eso fue lo que me quedó sin explicarte, por falta de tiempo. Mi madre era la tercera hermana de Thiele, y el único éxito del doctor Trevisan en su lucha contra la esterilidad. [...] antes de ser médico había sido inventor, y las retrató a las tres niñas faro de la casita de Arboleto. Pero yo soy una obra maestra, modestia aparte. Me había hecho inmune a las tracciones mecánicas, por eso sobreviví a la explosión. Me sumergió en el océano de genes sosteniéndome del pie, que fue la única parte que me quedó vulnerable. (159)
\end{abstract}

La mendiga plantea una temporalidad y espacialidad complejas. La representación del espacio y del tiempo se construye a partir de la fusión de la virtualidad televisiva con la realidad barrial de Flores que inicialmente se representa en la novela. La espaciotemporalidad del fragmento inicial del accidente de Rosa en una transitada calle de Flores se funde con una espacio-temporalidad otra, la de los personajes de la ficción televisiva (Cecilia Roth, Aldo o Lidia Catalano ${ }^{10}$ ), que acaba subsumiendo a la anterior. Una tercera espacio-temporalidad se inscribe en las referencias del narrador a guionistas o espectadores, para los que las dos realidades descritas anteriormente funcionan como materiales de ficción y consumo. Se trata del tiempo real en el que se consumen las imágenes-vidas virtuales de los protagonistas por parte de la audiencia televisiva: "La sobredeterminación merece un párrafo explicativo: el programa que Cecilia estaba protagonizando tenía una característica que los espectadores habían notado, los más sutiles desde la primera emisión, otros al correr de los meses... La única que seguía sin registrarla, hasta ahora, era ella” (44-5).

Lo televisivo en ocasiones vale de explicación para hechos aparentemente irrelevantes o secundarios a la narración. Sirva el fragmento citado para dar ejemplo de ello, y sirva, además, para apuntar una cuarta espacio-temporalidad en la narración: el tiempo en el que se ruedan las escenas. El barrio de Flores, en tamaño natural, funciona como escenario de la teleserie. Los hechos transcurren en la reproducción virtual del espacio urbano que llega a suplir el espacio extravirtual que, así, en nada se le diferencia. En ocasiones, una espaciotemporalidad (la de Cecilia en la ficción de la teleserie) atraviesa la otra (en este caso la de la realidad de su rodaje): "La ciudad estaba desierta, como después de la extinción de la especie... No debería ser así porque eran apenas las diez de la noche de un sábado, pero esas escenas de exteriores las habían filmado todas a las tres de la mañana” (47).

En la radical puesta en duda de la personajeidad de los sujetos ficcionales, ${ }^{11}$ al servicio del propósito lúdico del narrador, juega un papel central, asimismo, la virtualidad

\footnotetext{
${ }^{10}$ Exceptuando a Aldo, trasunto de Osvaldo Lamborghini y que el narrador incluye en buena parte de sus novelas, Cecilia y Lidia, personajes en la teleserie de la novela, se inspiran en la realidad televisiva extraliteraria: Cecilia Roth y Lidia Catalano, ambas actrices, han actuado juntas además de en Nueve lunas, en No toquen a la nena (1976) o Crecer de golpe (1976).

${ }^{11}$ Por crisis en la personajeidad entendemos, junto a Castilla del Pino, la transgresión de sus límites como condición de existencia: “cada personaje sabe -como lo sabe cada persona- dentro de qué límites ha de desenvolver su actuación. [...] Si los transgrede, o si por error su conducta resulta inadecuada, se expone a que sobrevenga una crisis de su personajeidad” (31).
} 
mediática. El personaje de Cecilia supone un caso particularmente interesante. Tomada de la realidad (extraliteraria), pero a partir de la virtualidad mediática de la televisión (real), se inserta en la novela con su nombre propio. ${ }^{12}$ Sin embargo, el personaje de Cecilia no incorpora su realidad humana extraliteraria, sino la del personaje que representa en la teleserie. La focalización del narrador implica una ambigüedad, un estar entre el personaje televisivo y el sujeto-actriz que lo representa. El narrador omnisciente se alterna con la perspectiva del narrador-espectador de la teleserie para construir un personaje híbrido entre la ficción televisiva y la realidad televisada:

Esa noche, cuando terminó el trabajo en la clínica, en lugar de ir directamente a su casa, Cecilia decidió pasar por el Piñeyro a ver a su paciente accidental [...] había una motivación, y bien cargada de verosímil: estaba la curiosidad por un caso humano con un matiz intrigante. [...] los guionistas habían adoptado una regla de oro de la que no se apartaban nunca [...] no quedaban hilos sueltos. [...] Si no dijo que iba a pasar por el Hospital Piñeyro fue porque de todos modos contaba con estar en su casa en unas dos horas, y por no recargar de diálogo una fugaz escena de enlace. (43-4)

A la inversa, la televisión se convierte en una marca de humanidad que distingue al ser humano real de los personajes de ficción, ${ }^{13}$ como nos explica el narrador en una de sus numerosas digresiones teóricas:

Aquí aparece una diferencia notable entre la gente de la realidad y los personajes de televisión. Los primeros, cuando vuelven a su casa del trabajo, cuando pasan una velada en el hogar, hacen ineludiblemente una cosa: mirar televisión. Los segundos no lo hacen nunca, o al menos no se los ve hacerlo, ni hacen ninguna alusión a que lo hagan. Es cierto que los personajes de la televisión, cuando vuelven a su casa y salen de la trama en la que están funcionando, desaparecen. Se disuelven en la materia televisiva, que es su razón de ser. (44)

En gran medida, los protagonistas de la novela se construyen como personajes virtuales, inscritos en entornos cibernéticos o televisivos, y personajes usuarios de esos entornos, tematizándose en la novela los modos en que manejan la realidad que los circunda según procedimientos característicos de los espacios cibernéticos o virtuales: con referencias claras a los dibujos animados o al videogame, Rosa, la mendiga, va deshaciéndose de los enanos que surgen a su paso, saltando de lugares inverosímiles, mediante la refracción de la luz lunar en su propia retina en forma de rayos láser. Usuarios y virtuales, todos los personajes encajan en ocasiones en la segunda de estas categorías,

${ }^{12}$ El disfraz del nombre propio es un recurso recurrente en la novelística de Aira, el propio Aira se transforma repetidas veces en Aira personaje, el Doctor de Las curas milagrosas del Doctor Aira (1998), la niña Aira de Cómo me hice monja (1993), o el escritor Aira de El congreso de literatura (1999) o Embalse (1992).

${ }^{13}$ Katherine Hayles propone la categoría de lo poshumano como un modo de pensarse el ser humano en relación a lo virtual, considerando su cuerpo, incluyendo su cerebro como entes autónomos, sin centro o esencia, en novelas como La guerra de los gimnasios (1991), en donde se produce una objetivación del cerebro en el exterior del cuerpo del protagonista, pero también esta definición de lo humano que se vincula a lo televisivo apunta una vez más a lo poshumano en Aira. 
elementos de una virtualidad que se halla condicionada por la invención de los guionistas. Sólo a veces, con el error, con el lapsus linguae -metáforas a menudo usadas por Aira para referirse a su poética- los personajes pueden modificar el guión que se les presenta, tienen la posibilidad de innovar:

-Los recién casados se fueron a vivir a Brelín. -¿Adónde? -A Brelín. [...]

-Perdón, Aldo... ¿ ¿No será Berlín? -No... ¡Brelín! Es una localidad... en el Gran Buenos Aires.

Cecilia se quedó cortada. Justo ella, prototipo de actriz estudiosa y previsora, que nunca se quedaba sin letra. Pero no era su culpa. Ni de los autores. Estaba segura de que el guión decía Berlín. La culpa era de este imbécil de Aldo, que había leído mal, a los apurones, un rato antes de filmar, como si aprenderse el papel fuera un trámite sin importancia. [...] no se daba cuenta de las consecuencias [...] en televisión no se podía volver atrás, así que ahora habría que cambiar sobre la marcha todo el argumento... Por su estúpido error quedaba sin efecto lo más interesante de la trama de aquí en adelante [...] quedarían sin usar las costosas filmaciones que habían ido a hacer a Alemania. (97-8)

La idea del fin, del acabamiento de los recursos estéticos y de la posibilidad de revolución y renovación en el arte, aparece tratada en La mendiga. El discurso metacrítico de la novela sugiere un proyecto estético que se vincula a la idea de creencia: "He descubierto, que aun lo imposible (creer en serio en lo que no se cree) es posible. Uno cree en sus historias, por ejemplo en su propia historia; el cerebro se amolda a la creencia a priori, no a posteriori y empezamos a pensar una vez completada la creencia” (160).

¿Qué pide el narrador que sus lectores crean a toda costa? Una primera respuesta nos lleva al viejo ¿es o se hace?, que tan bien definió Elvio Gandolfo. ${ }^{14}$ A menudo, la frustración de las expectativas y las continuas transgresiones del verosímil rozan la frivolidad. Los textos de Aira exigen un incómodo trabajo de lectura. En su ironía, que en ocasiones vuela por encima de las posibilidades de interpretación de sus lectores, en la apelación a la creencia, Aira quiere vincularse con el gesto vanguardista de Dadá en su versión duchampiana o rousseliana, como la crítica pone de relieve (Estrín; Contreras; García). Efectivamente, el autor inscribe, por boca del narrador y personajes, un proyecto estético que se reivindica autoconscientemente como vanguardista. Parece que reproducir el gesto del ready-made a partir del cruce de géneros televisivos como parte de un proyecto de transvalorización del arte, no explica suficientemente la obstinada reivindicación de realismo en el absurdo a la que asistimos en la novelística de Aira. En ocasiones, de un modo ambiguo, precisamente en los momentos de mayor caos en lo representativo, en la acumulación excesiva de sentidos contradictorios o de elementos absurdos, que destruye el verosímil del relato, encontramos las reivindicaciones explícitas de hallarnos ante la presencia de mayor realismo. Lo real, lo auténticamente real, para el narrador empieza en

14 "El método de Aira [...] sería el viejísimo ¿es o se hace?, usado como herramienta de seducción/ rechazo, en un marco de paradójica histeria serena; su velado proyecto, lograr que sus lectores no puedan resolver la pregunta (¿demasiado inteligente o demasiado idiota?) en cuanto a su propia figura y su propia obra” (citado en Contreras 129). 
los momentos en los que se colapsa la capacidad de la razón para manejar la información. La afirmación de un realismo de la disolución de lo real en los textos de Aira, tiene resonancias, desde nuestra perspectiva, lo pretenda o no su autor, que se vinculan al paradigma posmoderno en tanto cuestionamiento de la ontología que bebe de la tradición nihilista (Vattimo, El fin).

Es en este sentido que, en los valores de ocultamiento y desestabilización de la calidad de la obra que la novela de Aira confiere a lo audiovisual mediático, hallamos una idea de real como construcción compleja, en la que diferentes niveles de ficcionalidad televisiva se imbrican con el nivel de realidad mimética, que llega a desaparecer. Y este modo de crisis de lo real es una característica central en la literatura posmoderna. ${ }^{15}$ Desaparecido lo real como referente, la lectura del realismo que se vindica en los textos sólo es posible a partir de la redefinición de la realidad que éstos construyen, en un contexto posmoderno en el que la realidad compartida por autor y lectores, dada la penetración de la mediación audiovisual, deviene simulacro. Es en este sentido que podemos entender la reivindicación de realismo del proyecto desconstructivo aireano. El gesto o el silencio de Aira, sumados a ese aparato para la desconstrucción de las convenciones de lo que tradicionalmente comprendemos por real, que conforman su proyecto narrativo, encuentra eco en un nietzscheano "seguir soñando sabiendo que se está soñando", en el proyecto de la disolución o pérdida de lo real que Vattimo interpreta como chance ("La posmodernidad...”), como posibilidad posmetafísica de construir de nuevo a sabiendas de que todo es construido; desde el horizonte del fin de los metarrelatos, el deseo -creencia, realidad- de vanguardia. En un Buenos Aires televisivo, algunos párrafos de Aira bien pueden cobrar significación:

Hace un momento te decía que la historia terminó, Aldo. Pero eso no quiere decir que se hayan terminado todas las historias. Ahora vendrán otras, y después otras más... Y en todas las historias hay un pequeño objeto perdido, que nadie va a reclamar, como vos decís, y que sin embargo es importante. (156)

ConCLUSiones

Con el análisis del presente corpus, hemos querido poner de manifiesto la presencia de las tecnologías de la virtualidad audiovisual y de qué diversos modos éstas influyen en la composición de los objetos literarios. Lejos de representar una disolución del modelo tradicional del canon americano, leyéndose esa supuesta disolución como un crimen contra la literatura latinoamericana (Berry, citado en Volpi), muestran por el contrario la vitalidad de una literatura que interactúa con una realidad latinoamericana de fin de siglo, contradictoria, construida y mediada por lo audiovisual. La presencia de la tecnología, que funciona en Paz Soldán como horizonte de realidad en crisis de la joven generación latinoamericana, como nuevo espacio en el que repensar los vínculos del arte y la vida, en Courtoisie, como gramática con la que narrar y desautomatizar las versiones asentadas de los sucesos históricos, o, en Aira, desde la cotidianidad de esa fusión de la virtualidad con

${ }^{15}$ Como pone de relieve la crítica: África Vidal; Sánchez-Pardo; Calinescu; Hassan. 
lo real, televisión-narración ${ }^{16}$ como lenguaje que coadyuva a la explosión de lo verosímil y juega un papel en su discurso meta-artístico, supone una propuesta en cada uno de ellos para resituar el quehacer literario en el contexto contemporáneo. Propuestas, donde la ironía, la irrisión, pero también la necesidad de utopías, dialogan conflictivamente haciéndose imposible, sin riesgo de faltar a la verdad, aplicar las categorías de apocalípticos o integrados.

\section{BiBLIOGRAFÍA}

Achugar, Hugo. La biblioteca en ruinas: reflexiones culturales desde la periferia. Montevideo: Trilce, 1994.

África Vidal, Maria del Carmen. Hacia una patafísica de la esperanza: reflexiones sobre la novela posmoderna. Alicante: Universidad de Alicante, 1990.

Aira, César. La mendiga. Buenos Aires: Mondadori, 1998.

Baudrillard, Jean. El otro por sí mismo. Barcelona: Anagrama, 1994. La ilusión del fin. Barcelona: Anagrama, 1997.

"Videosfera y sujeto fractal”. Videoculturas de fin de siglo. Luciano Anceschi, ed. Madrid: Cátedra, 1990. 27-36.

Bechelloni, Giovanni. “¿Televisión-espectáculo o televisión-narración?” Videoculturas de fin de siglo. Luciano Anceschi, ed. Madrid: Cátedra, 1990. 55-63.

Calinescu, Matei. Cinco caras de la modernidad: modernismo, vanguardia, decadencia, kitsch, posmodernismo. Madrid: Tecnos, 1991.

Castilla del Pino, Carlos. "La construcción del self y la sobreconstrucción del personaje”. Teoría del personaje. Carlos Castilla del Pino, comp. Madrid: Alianza, 1989.

Cavallaro, Dani. Cyberpunk and Cyberculture. Londres: Athlone Press, 2000.

Contreras, Sandra. Las vueltas de César Aira. Rosario: Beatriz Viterbo, 2002.

Courtoisie, Rafael. Caras extrañas. Madrid: Lengua de Trapo, 2001. “Entrevista realizada en Montevideo” (8 de enero de 2004). Jesús Montoya Juárez (inédita).

Eco, Umberto. Apocalípticos e integrados. Barcelona: De Bolsillo, 2004.

Estrín, Laura. César Aira: el realismo y sus extremos. Buenos Aires: Ediciones del Valle, 1999.

Even-Zohar, Itamar. “Les règles d'insertion des ‘realèmes’ dans la narration”. Littérature 57 (Février, 1985): 109-18.

García, Mariano. La génesis de la diversidad: el problema de los géneros en la obra de César Aira. Tesis defendida en la Universidad Católica de Buenos Aires, 2004.

González Requena, Jesús. El discurso televisivo: espectáculo de la posmodernidad. Madrid: Cátedra, 1988.

\footnotetext{
${ }^{16}$ Frente a planteamientos como los de Virilio o Baudrillard que afrontan el fenómeno televisivo en su faceta espectacular más sombría, en opinión de Bechelloni la televisión funciona también como productora de historias, cuando el espectáculo deja de serlo sometido a la rutina cotidiana, haciéndose parte de nuestro modo de relacionarnos y percibir el mundo. Ese grado de desapasionamiento, de aceptación del hecho televisivo, parece hallarse en textos como La mendiga.
} 
Hassan, Ihab. Postmodern Turn: Essays in Postmodern Theory and Culture. Columbus: Ohio State UP, 1987.

Hayles, N. Katherine. How We Became Posthuman: Virtual Bodies in Cybernetics, Literature, and Mathematics. Chicago: U of Chicago P, 1999.

Hopenhayn, Martín. Ni apocalípticos ni integrados: aventuras de la modernidad en América Latina. Santiago: FCE, 1994.

Jameson, Fredric. El posmodernismo o la lógica cultural del capitalismo avanzado. Barcelona: Paidós, 1991.

"Posmodernismo y sociedad de consumo". La posmodernidad. Hal Foster, ed. Barcelona: Kairós, 2002. 165-86.

Landow, George P. Hypertext: The Convergence of Contemporary Critical Theory and Technology. Baltimore: John Hopkins UP, 1992.

Lipovetski, Gilles. La era del vacío. Barcelona: Anagrama, 1986.

Mignolo, Walter. Historias locales/diseños globales: colonialidad, conocimientos subalternos y pensamiento fronterizo. Madrid: Akal, 2003.

Montaldo, Graciela. “Un caso para el olvido: estéticas bizarras en la Argentina”. El Matadero 3 (Buenos Aires, 2004): 37-49.

Paz Soldán, Edmundo. Sueños digitales. Madrid: Alfaguara, 2000.

Ramos González, Rosario, “La 'fábula electrónica’: respuestas al terror político y las utopías informáticas en Edmundo Paz Soldán”. MLN 118 (2003): 466-91.

Sánchez-Pardo González, Esther. Postmodernismo y metaficción. Madrid: Editorial de la Universidad Complutense, 1991.

Todorov, Tzvetan. Introducción a la literatura fantástica. Buenos Aires: Tiempo Contemporáneo, 1972.

Vattimo, Gianni. El fin de la modernidad. Barcelona: Gedisa, 1987. “La posmodernidad: ¿una sociedad transparente?”. En torno a la posmodernidad. Andrés Ortiz-Osés, comp. Barcelona: Anthropos, 1999.

Verón, Eliseo. “Ficción televisiva e imaginario social”. El espectáculo de la pasión. Nora Maziotti, ed. Buenos Aires: Colihue, 1993. 29-41.

Villanueva, Darío. Theories of Literary Realism. Albany: SUNY Press, 1997.

Virilio, Paul. “El último vehículo”. Videoculturas de fin de siglo. Luciano Anceschi, ed. Madrid: Cátedra, 1990. 37-45.

Volek, Emil. Literatura hispanoamericana entre la modernidad y la postmodernidad. Bogotá: Serie Cuadernos de Trabajo de la Facultad de Ciencias Humanas, Universidad Nacional de Colombia, 1994.

Volpi, Jorge. “El fin de la narrativa latinoamericana”. Palabra de América. Adolfo García Ortega, comp. Barcelona: Seix Barral, 2004. 206-23.

Waisword, Silvio. “Interpretando los escándalos. Análisis de su relación con los medios y la ciudadanía en la Argentina contemporánea”. Controlando la política: ciudadanos y medios en las nuevas democracias latinoamericanas. Enrique Peruzzotti y Catalina Smulovitz, eds. Buenos Aires: Temas, 2001. 289-325. 